\title{
Seedling survival and growth of three ectomycorrhizal caesalpiniaceous tree species in a Central African rain forest
}

\author{
D. M. Newbery*1, G. B. Chuyong†, L. Zimmermann* and C. Praz*2 \\ * Institute of Plant Sciences, University of Bern, Altenbergrain 21, CH-3013 Bern, Switzerland \\ $\dagger$ Department of Life Sciences, University of Buea, P.O. Box 63, Buea, S.W. Province, Cameroon \\ (Accepted 31 March 2006)
}

\begin{abstract}
Tree recruitment is determined in part by the survivorship and growth of seedlings. Two seedling cohorts of the three most abundant caesalpiniaceous species forming groves at Korup, Cameroon, were followed from 1995/1997 to 2002, to investigate why Microberlinia bisulcata, the most abundant species, currently has very few recruits compared with Tetraberlinia korupensis and T. bifoliolata. Numbers of seedlings dying, and the heights and leaf numbers of survivors, were recorded on 30 occasions. Survivorship after 2.5 y was $30 \%$ for M. bisulcata and $59 \%$ for the similar Tetraberlinia spp. together. After $7 \mathrm{y}$ the corresponding values were 4 and $21 \%$. Growth of all species was slow for the first $4 \mathrm{y}$; but survivors of T. korupensis became $63 \%$ taller, as the other species stagnated, by $7 \mathrm{y}$. The poor recruitment of $M$. bisulcata was the result of its very low seedling survival. Within species, the tallest seedlings of M. bisulcata and T. bifoliolata, but medium-height ones of T. korupensis, survived longest. This was likely due to higher root allocation in T. korupensis. Seedling dynamics of M. bisulcata and T. korupensis over $7 \mathrm{y}$ accorded well with relative abundances of adult trees; T. bifoliolata is predicted to recruit later.
\end{abstract}

Key Words: Africa, grove dynamics, growth, Microberlinia, rain forest, seedlings, survivorship, Tetraberlinia

\section{INTRODUCTION}

Survivalthrough the first few years of establishment is an important component of fitness for tropical trees (Swaine 1996, Turner 2001). Temporarily better-than-average survival may lead to an overall population increase, lessthan-average survival may lead to a population decline (Botkin 1993, Shugart 1998). As a result, forest structure and composition, in terms of the relative abundances of different species in different size or age classes, is a complex compilation of recruitment and mortality over several decades (DeAngelis \& Gross 1992, Vanclay 1994). Population changes can be transient, part of a cycle or a successional sere, or even a long-term directional trend (Connell \& Slatyer 1977, Horn 1974). Cases where species clearly lack sufficient numbers of small trees, and failure to recruit has happened repeatedly, point to one or more factors keeping the population low, and leading to a possible decline or even local extinction of the

\footnotetext{
${ }^{1}$ Corresponding author. Email: david.newbery@ips.unibe.ch

${ }^{2}$ Present address: Institute of Plant Sciences, ETH-Zentrum, Schmelzbergstrasse 9, CH-8092 Zürich, Switzerland.
}

species (Condit et al. 1998, Newbery \& Gartlan 1996). Conversely, a relatively high abundance of small trees might suggest a wave of recruitment resulting in local dominance (Harper 1977, Jones 1950). The apparent imbalance in the numbers of trees of the different size classes necessary for continuous replacement (Connell et al. 1984, Hubbell \& Foster 1990) becomes particularly obvious when it concerns a dominant species in a speciespoor forest (Connell \& Lowman 1989, Richards 1996).

Where a species has very low recruitment within the patches of adult trees, it must find new locations away from adults in order to maintain the population. This could be either at the edge of existing patches if seed dispersal is poor, or further away as new patches if seed dispersal is good. The first process leads to a locally expanding patch periphery, perhaps followed later by fragmentation and decay at the centre (Newman 1982, Watt 1947). The second process allows for a mosaic in which old stands are dying and new ones are establishing elsewhere within the forest on a larger landscape scale. Whether a species is perceived to be persisting or not is clearly dependent on the scale of field measurements (DeAngelis \& Gross 1992, Shugart 1998). On a scale that is too small the dynamics may appear erratic and 
unpredictable; on a large scale encompassing several patches changes may even out at an equilibrium density. Further, the inability of a tree species to replace itself in situ might appear to be selectively disadvantageous. However, if the conditions under which the species came to establish were different from those that it created later as a dominant tree there would be selective advantages in dispersing (Connell \& Slatyer 1977, Huston \& Smith 1987).

Adult trees of some tropical trees, when they reach a certain density or threshold biomass, can be hypothesized to affect the environment so as to curtail severely their own recruitment. This could be brought about by changes to the physical environment to which their seedlings are not well adapted: e.g. decreasing light and nutrient availability (Longman \& Jenik 1987) or to biological changes such as the build up of species- or guild-specific predators or pathogens (Connell 1971, Janzen 1970). The basis to this process is the concept of cyclical dynamics, of establishment, growth, dominance, and then dispersal and re-establishment elsewhere paralleled with decay of old stands (Richards 1996, Swaine \& Hall 1988, Watt 1947, Whitmore 1984). In such dynamics the (lack of) establishment of seedlings probably plays an important role. Key questions to be asked are: (1) what is the recruitment potential of each species; (2) which factors determine the rate of decline in survivorship; (3) do co-occurring species regenerate better, and why; and (4) what are the consequences of the relative survivorship rates for the species composition of the tree population?

A suitable ecosystem in which to follow these ideas is offered by groves of large tree species in the rain forests of western Central Africa, particularly in the Atlantic Coastal forests of Cameroon (Letouzey 1968, 1985; Schnell 1976-77, White 1983). In this region a 200-kmwide arc inland of the Bay of Biafra is characterized by several abundant, closely related species in the family Caesalpiniaceae (Leguminosae). Their distributions vary in spatial extent and composition from large almost monodominant tracts of forest through to patches of differing sizes with a few to several species of closely related taxa. Some have more-or-less good in situ regeneration whilst others appear to be decaying because of the evident lack of recruits (Condit et al. 1998, Letouzey 1968). A low density of juvenile trees may, however, not be reason alone for population decline if the few small trees have very high rates of survivorship to adulthood and high growth rates (Clark \& Clark 1987, Jones 1956, Poorter et al. 1996).

This mosaic form of dynamics in African forests, necessarily understood on large spatial and temporal scales, was first recognized by Aubréville (1938), and elaborated by Letouzey $(1968,1985)$. Newbery \& Gartlan (1996) evaluated the idea by analysing two large data sets from Cameroon. The process was highlighted by Richards
(1996) as being one of the intrinsically differentiating features of African, as opposed to South and Central American and South-East Asian rain forests, and as being an example of the 'pattern and process' concept formulated by Watt (1947). This so-called 'Aubréville phenomenon' (Newbery et al. 1998, 2004) still remains largely unexplained in terms of a set of general working mechanisms. An essential component of this type of forest dynamics may lie with recruitment from seed to seedlings and saplings, which is the subject of the present paper.

Given their importance in explaining subsequent forest composition, reports of demographic studies in the tropical rain forests which followed the survivorship of defined seedling cohorts $\geq 5 \mathrm{y}$ are surprisingly rare. Important cases are Dipteryx panamensis (Papilionaceae, Leguminosae) in Costa Rica over 5 y (Clark \& Clark 1987), Vouacapoua americana (Papilion.) in French Guiana over 10 y (Forget 1997), and Chrysophyllum sp. nov. (Sapotaceae) in Queensland, Australia over $27 \mathrm{y}$ (Connell \& Green 2000). Survival percentages were 3, 11 and $6 \%$ for the three cases respectively. Other studies which have followed survivorship of populations present in the seedling bank from a particular starting time for $\geq 5 \mathrm{y}$ (e.g. Delissio et al. 2002, Hart 1995) had the disadvantage that ages and cohort structure were unknown. Many more attempts have been made to record short-term survival, typically for $1-3 \mathrm{y}$, which may give misleading indications of the longer term dynamics and recruitment of the species concerned.

In this paper a long-term study of the seedling demography of three large caesalpiniaceous tree species exemplifying Aubréville dynamics is reported for a site in Central Africa. The results are related to what is known of the species' current sapling and tree densities.

\section{STUDY SITE AND SPECIES}

In the southern part of Korup National Park, in South West Cameroon, three large caesalpiniaceous tree species, Microberlinia bisulcata A. Chev., Tetraberlinia bifoliolata (Harms) Hauman and T. korupensis Wieringa (previously identified in Korup as T. moreliana Aubrév.), form large groves (Newbery et al. 1988, 1997, 1998, 2004). These canopy-emergent trees are fully intermixed with one another across the main grove of $c .1 .5 \mathrm{~km} \times 1.0 \mathrm{~km}$ in area, forming close to $50 \%$ of all trees $\geq 50 \mathrm{~cm}$ stem diameter (Newbery et al. 1998) and up to c. $70 \%$ of the basal area in 0.64-ha plots (Gartlan et al. 1986, Newbery et al. 1997). There are several other species of the subfamily within and outside of the groves (Newbery et al. 1988) but the most significant characteristic is that almost all of the caesalpiniaceous species are in the tribe Amherstieae and are ectomycorrhizal (Alexander 1989a, 
Alexander \& Högberg 1986, Newbery et al. 1988). The groves (of which two others are now been studied in Korup: Newbery et al. 2004 and X. M. van der Burgt and D. M. Newbery, unpubl. data) are established on phosphorus-poor, sandy, acidic and strongly leached soils where ectomycorrhizal status is likely to be the principal reason for their selection and codominance (Newbery \& Gartlan 1996, Newbery et al. 1997).

An interesting feature of this forest is that despite its dominance $M$. bisulcata clearly lacks many small stems: recruitment is apparently very poor. There are very few small trees and hardly any saplings in comparison to the numbers of adults, as would be expected if some form of continuous replacement was in progress to achieve a stable size (or age) distribution over time. Furthermore, sizes of the large trees have a unimodal distribution, the most frequent trees having stem diameters of c. $1.1 \mathrm{~m}$ (maximum $2.5 \mathrm{~m}$ ). By comparison, T. bifoliolata and T. korupensis are well stocked in the intermediate and small-size stem classes (maximum $1.5 \mathrm{~m}$ ), with T. korupensis having more trees $10-<50 \mathrm{~cm}$ diameter than T. bifoliolata (Newbery et al. 1988, 1998). Together these distributions lead to the suggestion that $M$. bisulcata, in at least the main grove on transect P (see Gartlan et al. 1986) may die out in time and be replaced either by T. bifoliolata and then T. korupensis in succession or by a mixture of them both simultaneously (Newbery et al. 1998). One recently discovered grove of M. bisulcata in Korup in 2004 (X. M. van der Burgt and D. M. Newbery, unpubl. data) was shown to have a higher proportion of juvenile trees, however, and this demonstrates a likely continuation of the species.

The three caesalpiniaceous species share a similar floral and pollination biology, means of seed dispersal, germination and establishment strategy. Mast fruiting occurs every 2-3 y (Green \& Newbery 2002, Newbery et al. 1998, 2006) which means that distinct cohorts are regularly established. Pods mature in May-October, and then split and explosively throw out their seeds up to 50-70 m away from the canopy. Epigeal germination produces two fleshy cotyledons within 1 wk of seed fall (Green \& Newbery 2001a, 2002). In this way, seedling banks of the three species are started within $c .3 \mathrm{wk}$ of one another (Newbery et al. 1998, 2006) and comparative survivorship can then be followed knowing the exact ages of the plants. Mast fruiting leads to very large numbers of seedlings, e.g. M. bisulcata adults (trees with stem diameters $\geq 50 \mathrm{~cm}$ ) produced on average 83500 seeds $\mathrm{ha}^{-1}$ in 1995, of which $12960 \mathrm{ha}^{-1}(16 \%)$ germinated and established as new seedlings (Green \& Newbery 2002). Microberlinia bisulcata and T. korupensis have similarly sized microphyllous pinnate leaves $(8-16$ pairs, leaflets $c .8 \mathrm{~mm} \times 20 \mathrm{~mm}$ ) but $T$. bifoliolata has fewer mesophyllous, pinnate, leaves (two large leaflets $c .2 \mathrm{~cm} \times$ $5 \mathrm{~cm}$ ) (Aubréville 1970).

\section{METHODS}

In the eastern 25 ha of the main 82.5-ha plot in Korup (on transect ' $\mathrm{P}$ ' of Gartlan et al. 1986), one 4-m $\times 4-\mathrm{m}$ quadrat was established at random close to every 50-m grid-line intersection internal to this $500-\mathrm{m} \times$ 500-m area, plus 10 further quadrats selectively in the remaining part of the plot $(\mathrm{n}=91)$. In November 1995, directly after seed fall and germination of the new cohort, 26 quadrats with sufficient numbers of seedlings $(\mathrm{n} \geq 8)$ of M. bisulcata, T. korupensis and T. bifoliolata were selected. Each seedling received a numbered aluminium tag. Counts of seedlings were first made on 14 December 1995 $\left(t_{0}\right)$. On 27 further occasions $\left(t_{1}-t_{27}: 26\right.$ January 1996 to 25 June 1998) the alive/dead status of each seedling was recorded, together with the height $(\mathrm{cm})$ and number of leaves of each survivor. Each census took 3-4 d to complete and the median dates have been used. The mean $( \pm$ SE) interval length was $34 \pm 2 \mathrm{~d}(\mathrm{n}=27)$. Number of days (nd) from $t_{0}$ was very closely linearly related to interval number (int) (nd $=-3+32.4 \mathrm{int}, \mathrm{r}^{2}=0.998$, $\mathrm{P} \ll 0.001)$. The quadrats were later inspected on 16 December $1999\left(t_{28}\right)$, 14 March $2000\left(t_{29}\right)$ and 4 February $2003\left(t_{30}\right)$. The time spans between $t_{0}$ and $t_{27}$, mid $t_{28} / t_{29}$ and $t_{30}$ were $2.53,4.13$ and $7.14 \mathrm{y}$ respectively.

From $t_{21}$ (30 September 1997, $1.79 y$ from $t_{0}$ ) a second cohort of seedlings was recorded in the same quadrats. These were tagged and recorded in the same way as for the first cohort, until $t_{30}$. The total number of seedlings followed was 1519, consisting of 994 in cohort $1\left(\right.$ at $\left.t_{0}\right)$ and 525 in cohort $2\left(t_{21}-t_{22}\right)$. Thirty-four seedlings (almost all in one quadrat) were cut at ground level (presumably by rodents or ungulates) at $t_{7}$ (33 M. bisulcata and one T. bifoliolata). These were removed from the data set to leave 1485 seedlings in total and 960 in cohort 1 . The numbers of starting seedlings in cohort 1 were therefore 391, 209, 360 for M. bisulcata, T. korupensis and T. bifoliolata respectively, and in cohort 2 correspondingly 200, 201 and 124 . Appendix 1 shows the starting numbers of seedlings per quadrat.

Photosynthetically active radiation (PAR) and the ratio of red to far-red light (R:FR) were recorded on 28-31 May 1998, in each of the quadrats with the focus species, following the method of Green \& Newbery (2001b). Climate data were available from the Bulu Station, Ndian, bordering the National Park. Dry seasons within the first $2.5 \mathrm{y}$ of intensive sampling occurred when the 30-d running totals of daily rainfall fell below $100 \mathrm{~mm}$ (Newbery et al. 2006). They were 11 January 1996-29 February 1996 (50 d), 24 December 199621 March 1997 (88 d) and 28 December 1997-14 March 1998 (77 d).

To examine the trends from $t_{0}$ to $t_{27}$ all time intervals were considered. From $t_{0}$ to $t_{30}$, because the intervals 
were much longer between $t_{27}$ and $t_{28}$ and $t_{29}$ and $t_{30}$ than within $t_{1}-t_{27}$, sets of times at intervals $>0.5 \mathrm{y}$ were taken as follows: start numbers at $t_{0}$ (cohort 1 ) or $t_{21}$ (cohort 2), and then mean numbers surviving, height or leaf number for: $t_{1}-t_{3}, t_{9}-t_{11}, t_{17}-t_{19}, t_{25}-t_{27}, t_{28}-t_{29}$ and $t_{30}$ (cohort 1); and $t_{25}-t_{27}, t_{28}-t_{29}$ and $t_{30}$ (cohort 2 ). The mean dates of these points in time were found. Data analysis was accomplished using FORTRAN_77 programs, followed by statistical testing with GenStat 7/8, S-Plus 6.1 and MiniTab 14 software. Survival analysis was guided principally by Kleinbaum (1996) and Lee (1992).

\section{RESULTS}

\section{Survivorship}

In cohort 1 for the first $2.5 \mathrm{y}$, Microberlinia bisulcata declined in proportion close to half that of Tetraberlinia bifoliolata and T. korupensis, to $29.9 \%$ and a mean of $58.8 \%$ respectively (Figure 1a). After $7.1 \mathrm{y}$ the corresponding survival was $3.6 \%$ and $21.2 \%$ (Figure 1 b). Tetraberlinia korupensis survived slightly better than T. bifoliolata at 2.5 and $7.1 \mathrm{y}$. For cohort 2 the differences were less clear at $2.5 \mathrm{y}$ (Figure 1a) but by $7.1 \mathrm{y} \mathrm{T}$. bifoliolata survived almost equally as poorly as M. bisulcata (mean $7.6 \%$ ) compared with T. korupensis (34.8\%) (Figure 1b). Thus whilst M. bisulcata and T. korupensis showed similar results in both cohorts, T. bifoliolata survived less well in cohort 2 than 1 . Percentage survival $(\%$, points in Figure 1a) declined exponentially with time $(\mathrm{t})$ for all species $(M$. bisulcata: $\ln (\% \mathrm{~S})=4.58-0.466 \mathrm{t}, \mathrm{F}=$ 3771; T. korupensis: $\ln (\% \mathrm{~S})=4.61-0.213 \mathrm{t}, \mathrm{F}=1826$; T. bifoliolata: $\ln (\% \mathrm{~S})=4.58-0.226 \mathrm{t}, \mathrm{F}=1328 ; \mathrm{df}=1,5$ and $\mathrm{P} \ll 0.001$ in all cases). This implies that the hazard rates were close to constant: $S_{t}$ was 62.3, 80.8 and $79.7 \%$ of $\mathrm{S}_{\mathrm{t}-1}$ for M. bisulcata, T. korupensis and T. bifoliolata respectively. The corresponding half-lives of the populations $\left(\mathrm{t}_{1 / 2}\right)$, found from the equations, were $1.43,3.28$ and $2.96 \mathrm{y}$. For cohort 2 (Figure 1b), with fewer points, $\% \mathrm{~S}$ also declined exponentially $(M$. bisulcata: $\ln (\% \mathrm{~S})=5.29-0.449 \mathrm{t}$; $\mathrm{F}=142 ;$ T. korupensis: $\ln (\% \mathrm{~S})=4.81-0.182 \mathrm{t}, \mathrm{F}=34.4$; T. bifoliolata: $\ln (\% \mathrm{~S})=5.17-0.460 \mathrm{t}, \mathrm{F}=53.9 ; \mathrm{df}=1,2$; $\mathrm{P}<0.03$ in all cases), and $\mathrm{S}_{\mathrm{t}}$ was correspondingly 63.8 , 83.4 and $63.1 \%$ of $S_{t-1}$. In cohort 2 the time series was too short to estimate $\mathrm{t}_{1 / 2}$ reliably.

Differences in survival in cohort 1 between $M$. bisulcata and T. korupensis and between $M$. bisulcata and T. bifoliolata, based on Kaplan-Meier curves, were highly significant $\left(\chi^{2}=35.4, \mathrm{df}=1, \mathrm{P}<0.001\right.$, both cases $)$, but not between T. korupensis and T. bifoliolata $\left(\chi^{2}=0.08\right.$, $\mathrm{df}=1, \quad \mathrm{P}=0.362)$. Cox proportional-hazards ratios
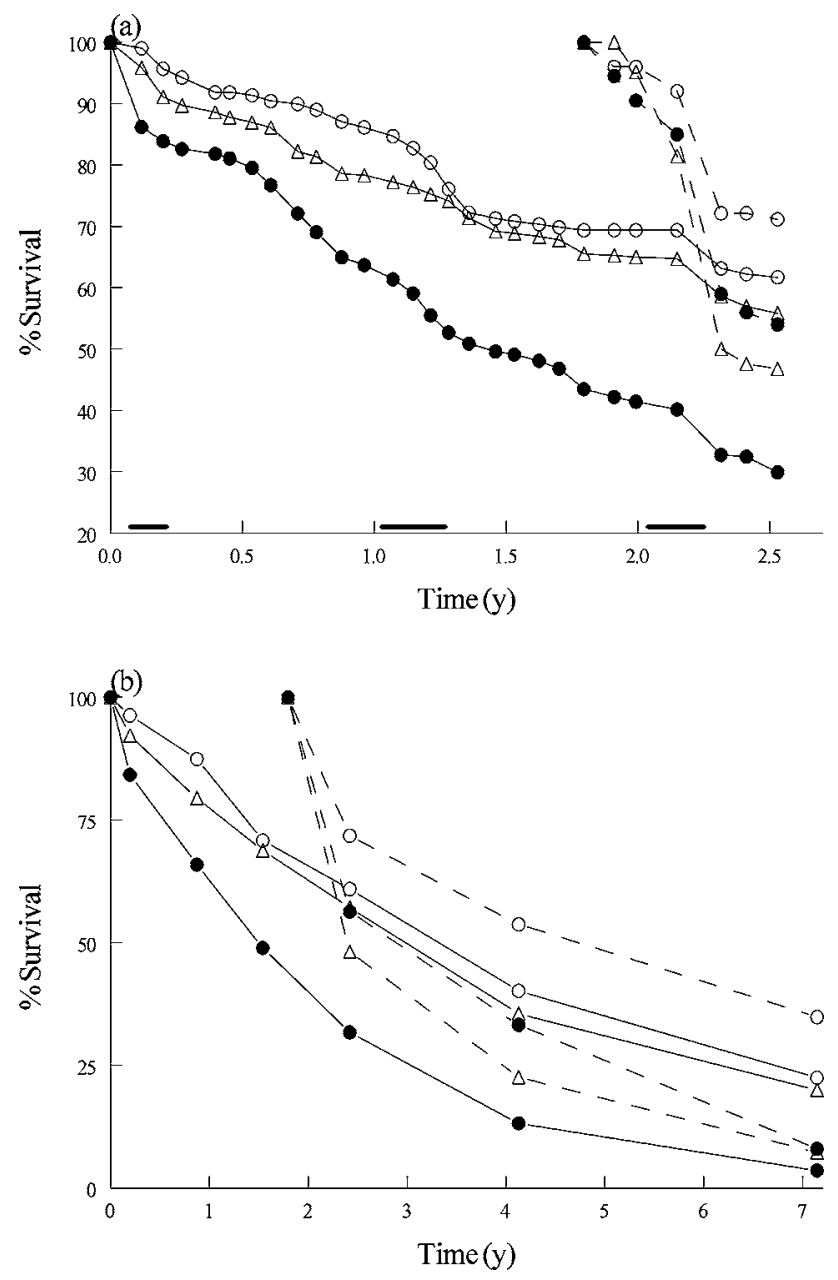

Figure 1. Percentage survival of seedlings of Microberlinia bisulcata (closed circles), Tetraberlinia korupensis (open circles) and T. bifoliolata (open triangles) in cohort 1 (1995, solid lines), and cohort 2 (1997, dashed lines) from recording times (a) $t_{0}$ to $t_{27}$ and $t_{21}$ to $t_{27}$ at short intervals, and (b) $t_{0}$ to $t_{30}$ and $t_{21}$ to $t_{30}$ at long intervals. The starting dates were 14 December $1995\left(t_{0}\right)$ for cohort 1 and 30 September $1997\left(t_{21}\right)$ for cohort 2. In (b), apart from $t_{30}$, points are means of two $\left(t_{28-29}\right.$ both cohorts, $t_{21-22}$ cohort 2), otherwise three successive counts. Bars along the time axis indicate the dry seasons.

were 0.465 for M. bisulcata/T. korupensis, 0.730 for M. bisulcata/T. bifoliolata, and 1.137 for T. korupensis/ T. bifoliolata (with likelihood ratio and log-rank tests giving statistical values very close to the $\chi^{2}$ ones).

For each species, those of the 26 quadrats which had $\geq 10$ individuals at $t_{0}$ were found. For M. bisulcata, T. korupensis and T. bifoliolata there were 10,5 and 10 such quadrats respectively (Appendix 1). Survival differences (with the Kaplan-Meier model) showed that for each species there were significant differences between quadrats $\left(M\right.$. bisulcata: $\chi^{2}=48.7, \mathrm{df}=9, \mathrm{P}<0.0001$, T. korupensis: $\chi^{2}=10.5, \mathrm{df}=4, \mathrm{P}=0.0327$; T. bifoliolata: $\left.\chi^{2}=50.4, \mathrm{df}=9, \mathrm{P}<0.0001\right)$. Proportions of seedlings 
surviving to $t_{27}$ were not significantly related to either mean PAR or mean R:FR $(\mathrm{P} \geq 0.1)$.

Mean proportions of survivors of M. bisulcata in cohort 1 at $\mathrm{t}_{1}-\mathrm{t}_{3}, \mathrm{t}_{9}-\mathrm{t}_{11}, \mathrm{t}_{17}-\mathrm{t}_{19}, \mathrm{t}_{25}-\mathrm{t}_{27}, \mathrm{t}_{28}-\mathrm{t}_{29}$ and $\mathrm{t}_{30}$ were not significantly dependent upon seedling numbers at $t_{0}$, (GLM logit regression; $\mathrm{n}=12$ quadrats with range 553 seedlings; $\mathrm{P}>0.05$ ). The other species had too few quadrats to test for density-dependence.

Mean PAR and R:FR ( \pm SE, range, median, $n=26)$ over the study quadrats (at $\mathrm{t}=2.45 \mathrm{y}$ in Figure 1 ) were $1.23 \%( \pm 0.15,0.43-3.25,1.14)$ and $0.357( \pm 0.019$, $0.16-0.54,0.340)$ respectively. Quadrats were classified according to whether, in cohort 1 , either M. bisulcata $(\mathrm{n}=8)$, T. korupensis (4) or T. bifoliolata (10) were dominant ( $n$ at $t_{0} \geq 50 \%$ of all three species). Species' quadrats did not differ in mean PAR $(\mathrm{F}=0.67, \mathrm{df}=2,19$; $\mathrm{P}=0.525)$, but they did in mean $\mathrm{R}: \mathrm{FR}(\mathrm{F}=8.45$, $\mathrm{df}=2,19 ; \mathrm{P}=0.002)$ with $M$. bisulcata occurring at the highest $(0.435 \pm 0.016, \mathrm{SE}), T$. korupensis at the intermediate $(0.349 \pm 0.031)$, and T. bifoliolata at the lowest $(0.240 \pm 0.035)$ levels.

\section{Growth}

Seedlings of $M$. bisulcata in cohort 1 were smaller than those of T. bifoliolata and T. korupensis at $\mathrm{t}_{0}$ (Figure 2; judging from the SEs) and by $t_{4}$ the order in height was T. bifoliolata $>T$. korupensis $>M$. bisulcata, and this was maintained to $t_{27}$. In cohort 2 the three species started at $\mathrm{t}_{21-22}$ with very similar heights (Figure 2a), but by $\mathrm{t}_{27}$ they had the same ordering as in cohort 1 . Growth rates, however, were in the order T. bifoliolata $>M$. bisulcata $\geq$ T. korupensis for cohort 1 and $M$. bisulcata $>T$. korupensis $>$ T. bifoliolata for cohort 2 (Table 1). Height increased almost linearly with time (Figure 2a) although second-order polynomials gave better fits $(\mathrm{Mb}$, $\mathrm{ht}=18.5+2.97 \mathrm{t}-0.285 \mathrm{t}^{2}, \mathrm{r}^{2}=0.991 ; \mathrm{Tk}, \mathrm{ht}=20.4+$ $2.58 \mathrm{t}-0.138 \mathrm{t}^{2}, \quad \mathrm{r}^{2}=0.989 ; \quad \mathrm{Tb}, \mathrm{ht}=20.3+4.12 \mathrm{t}-$ $0.506 \mathrm{t}^{2}, \mathrm{r}^{2}=0.994$; for all, $\mathrm{df}=25, \mathrm{P} \ll 0.001$ ).

Seedlings of $M$. bisulcata in cohort 1 had more leaves than either T. korupensis or T. bifoliolata at $\mathrm{t}_{0}$ (Figure 3a), and the order of M. bisulcata $>$ T. bifoliolata $>T$. korupensis was maintained to $\mathrm{t}_{24}$ (T. korupensis having half the number of $M$. bisulcata and T. bifoliolata) and from then on M. bisulcata and T. bifoliolata switched ranks. Although the trends were roughly linear for leaf number overall (Figure 3a), they were less easily fitted by polynomial equations. The curves for M. bisulcata and T. korupensis showed steps (these indicating leaf flushes) at $\mathrm{t}_{10}$ and $\mathrm{t}_{15}$. Cohort 2 had the same ordering as cohort 1 (Figure 3a). Rates of increase in leaf number were in the order T. korupensis $\geq T$. bifoliolata $>M$. bisulcata in cohort 1 , but T. korupensis $>$ M. bisulcata $>$ T. bifoliolata in cohort 2 (Table 1). Points in Figures 2 and 3 are the mean heights,
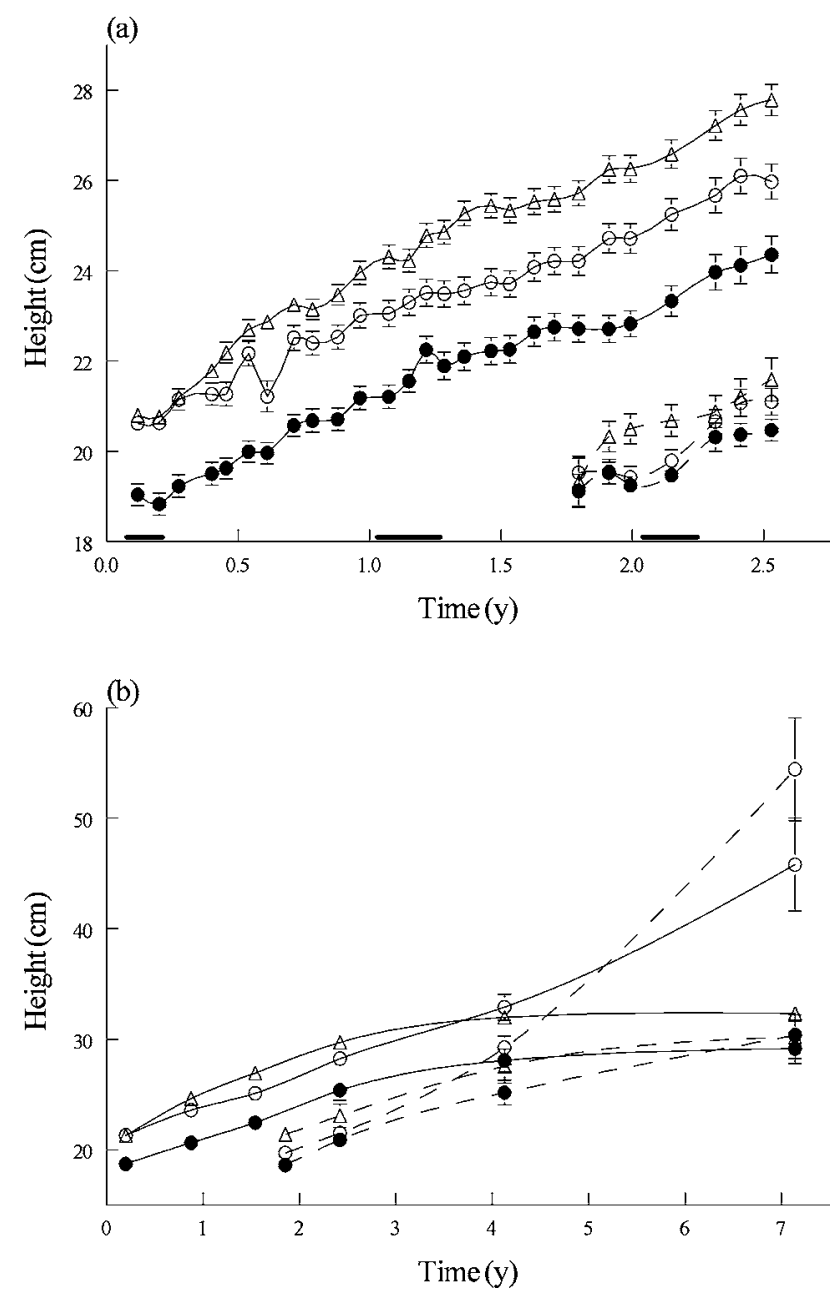

Figure 2. Change in height of seedlings of Microberlinia bisulcata (closed circles), Tetraberlinia korupensis (open circles) and T. bifoliolata (open triangles) in cohort 1 (1995, solid lines) and cohort 2 (1997, dashed lines) from recording times (a) $t_{0} t_{2} t_{27}$ and $t_{21}$ to $t_{27}$, and (b) $t_{0}$ to $t_{30}$ and $t_{21}$ to $t_{30}$. The starting dates were as in Figure 1. In (a) the first points for cohort 2 are means of values at $t_{21}$ and $t_{22}$. In (b) the same comments apply as in Figure 1. Bars on points show \pm 1 SE. Horizontal bars along the time axis indicate the dry seasons.

and leaf numbers, of seedlings alive at those times, but the rates calculated in Table 1 are for seedlings which survived until either $t_{27}$ or $t_{30}$.

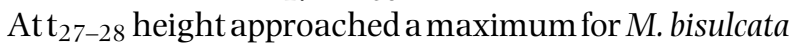
and T. bifoliolata so that by $\mathrm{t}_{30}$ cohorts 1 and 2 had similar values (Figure 2b). By contrast, T. korupensis increased considerably from $t_{28-29}$ to $t_{30}$ by 39 and $86 \%$ in cohorts 1 and 2 respectively. Whilst growth rates of $t_{30}$-survivors were more similar up to $t_{27}$ in cohort 1 (Table 1 ), by $t_{30}$ rates of T. korupensis were 2-3-fold those of $M$. bisulcata and T. bifoliolata in cohorts 1 and 2 (Table 1 ). Leaf numbers increased in a similar manner to height up to $t_{30}$ for $\mathrm{t}_{30}$-survivors (Figure $3 \mathrm{~b}$ ), though with small decreases in mean number between $\mathrm{t}_{28-29}$ and $\mathrm{t}_{30}$ for $M$. bisulcata and T. bifoliolata (Table 1), but increasing by 61 and $139 \%$ for 
Table 1. Growth rates (agr, absolute; rgr, relative) in seedling height and leaf number of Microberlinia bisulcata, Tetraberlinia korupensis and T. bifoliolata in Korup, for cohorts 1 (1995) and 2 (1997) in the first 2.5 y (to t $_{27}$ ) and 7.1 y (to t $_{30}$ ).

\begin{tabular}{|c|c|c|c|c|c|}
\hline \multirow[b]{2}{*}{ Species } & \multirow[b]{2}{*}{$\mathrm{n}$} & \multicolumn{2}{|c|}{ Height } & \multicolumn{2}{|c|}{ Leaf number } \\
\hline & & $\operatorname{agr}\left(\mathrm{cm} \mathrm{y}^{-1}\right)$ & $\operatorname{rgr}\left(\mathrm{cm} \mathrm{cm}^{-1} \mathrm{y}^{-1}\right)$ & $\operatorname{agr}\left(\mathrm{Ny}^{-1}\right)$ & $\operatorname{rgr}\left(\mathrm{N} \mathrm{N}^{-1} \mathrm{y}^{-1}\right)$ \\
\hline \multicolumn{6}{|l|}{ Cohort 1} \\
\hline \multicolumn{6}{|l|}{ Survivors to $\mathrm{t}_{27}$} \\
\hline Growth $\mathrm{t}_{1-3}-$ & & & & & \\
\hline M. bisulcata & 113 & 2.30 & 0.107 & 0.73 & 0.142 \\
\hline T. korupensis & 129 & 2.30 & 0.099 & 1.07 & 0.352 \\
\hline T. bifoliolata & 198 & 2.97 & 0.123 & 1.16 & 0.230 \\
\hline \multicolumn{6}{|l|}{ Survivors to $t_{30}$} \\
\hline \multicolumn{6}{|c|}{ Growth $\mathrm{t}_{1-3}-\mathrm{t}_{25-27}$} \\
\hline M. bisulcata & 14 & 3.00 & 0.137 & 1.47 & 0.253 \\
\hline T. korupensis & 47 & 3.12 & 0.127 & 1.56 & 0.442 \\
\hline T. bifoliolata & $72^{\mathrm{a}}$ & 3.80 & 0.151 & 1.88 & 0.326 \\
\hline \multicolumn{6}{|l|}{ Survivors to $t_{30}$} \\
\hline \multicolumn{6}{|c|}{ Growth $t_{1-3}-t_{30}$} \\
\hline M. bisulcata & 14 & 1.50 & 0.064 & 0.50 & 0.084 \\
\hline T. korupensis & 47 & 3.53 & 0.110 & 1.60 & 0.267 \\
\hline T. bifoliolata & $72^{\mathrm{a}}$ & 1.59 & 0.060 & 0.18 & 0.039 \\
\hline \multicolumn{6}{|l|}{ Cohort 2} \\
\hline \multicolumn{6}{|l|}{ Survivors to $t_{27}$} \\
\hline \multicolumn{6}{|c|}{ Growth $\mathrm{t}_{21-22}-\mathrm{t}_{25-27}$} \\
\hline M. bisulcata & $108(82)^{b}$ & 4.04 & 0.205 & 2.58 & 0.570 \\
\hline T. korupensis & $142(103)^{b}$ & 3.19 & 0.155 & 1.02 & 0.450 \\
\hline T. bifoliolata & $56(49)^{\mathrm{b}}$ & 3.00 & 0.135 & 0.26 & 0.064 \\
\hline \multicolumn{6}{|l|}{ Survivors to $t_{30}$} \\
\hline Growth $t_{21-2}$ & & & & & \\
\hline M. bisulcata & $16(9)^{b}$ & 2.23 & 0.093 & 0.69 & 0.127 \\
\hline T. korupensis & $70(46)^{\mathrm{b}}$ & 6.59 & 0.192 & 2.58 & 0.390 \\
\hline T. bifoliolata & $9(8)^{b}$ & 1.67 & 0.065 & 0.38 & 0.077 \\
\hline
\end{tabular}

${ }^{\mathrm{a}}: \mathrm{n}=71$ for $\mathrm{t}_{25-27}{ }^{\mathrm{b}}: \mathrm{n}$ in parenthesis for $\mathrm{t}_{21}$ and $\mathrm{t}_{22}$ averaged.

cohorts 1 and 2 for T. korupensis (Figure 3b). In summary, irrespective of the starting differences, M. bisulcata and T. bifoliolata stagnated in height and leaf number, whilst T. korupensis increased on average by $63 \%$ in height over the later $3 \mathrm{y}$.

The frequency distributions of heights and leaf numbers of seedlings of T. korupensis reaching $\mathrm{t}_{30}$ in cohorts 1 and 2 were positively skewed (Figure 4). In cohort 1 , $38 \%$ of seedlings had heights $\geq 40 \mathrm{~cm}(21 \% \geq 60 \mathrm{~cm}$, $6.4 \% \geq 120 \mathrm{~cm}$ ) whilst in cohort 2 the corresponding values were $57 \%(31,4.3)$. Similarly, $23.4 \%$ of seedlings had $\geq 20$ leaves $(4.3 \% \geq 50)$; in cohort 2 the values were $28.6 \%(4.3 \%)$. Back-transforming from $\ln$-transformed data gave mean heights (with 95\% confidence limits) of $40.2 \mathrm{~cm} \mathrm{(35.0-46.2)} \mathrm{for} \mathrm{cohort} 1$ and $44.5 \mathrm{~cm} \mathrm{(38.3-}$ 51.7 ) for cohort 2. Likewise, means and limits of leaf numbers were 8.63 (6.56-11.4) and 10.0 (7.89-12.7) for cohorts 1 and 2 respectively. Thus, accounting for the non-normality of the data, mean height and leaf number of T. korupensis still remained above those of M. bisulcata and T. bifoliolata at $\mathrm{t}_{30}$ (cf. Figure $2 \mathrm{~b}$ and $3 \mathrm{~b}$, displaying $\mathrm{SE}$ ). The shapes of the distributions were similar between cohorts for leaf number (Figure $4 \mathrm{~b}$ ), but that for height in cohort 2 had a clear peak at $c .50 \mathrm{~cm}$ which was absent in cohort 1 (Figure 4a). Height and leaf number
(In-transformed) were strongly correlated in cohort 1 $(\mathrm{r}=0.828, \mathrm{df}=45, \mathrm{P}<0.001)$ and cohort $2(\mathrm{r}=0.847$, $\mathrm{df}=68, \mathrm{P}<0.001)$. There were too few quadrats $(\mathrm{n}=5)$ to permit a test of whether height of T. korupensis was related to PAR.

There were no clear associations between survivorship, height and leaf number growth of the three species with dry season, except for an increase in leaf number of longest surviving seedlings of M. bisulcata and T. bifoliolata in the second dry season of 1996-97 (Figure 3a and $5 b, f)$. However, another similar increase occurred in the following wet season of the same year, yet none in the next dry season (1997-98).

\section{Survival and earlier growth}

Growth curves of seedlings surviving to set time intervals $\left(t_{7}-t_{12}, t_{13}-t_{18}, t_{19}-t_{24}, t_{25}-t_{30}\right)$ show different patterns for the species; seedlings of greater height and more leaves at the start did not always survive the longest (Figure 5). Microberlinia bisulcata and T. bifoliolata behaved very similarly but differently from T. korupensis. From $\mathrm{t}_{1}$ to $c$. $\mathrm{t}_{10}, M$. bisulcata and T. bifoliolata increased in height generally in parallel, with the early-dying seedlings 

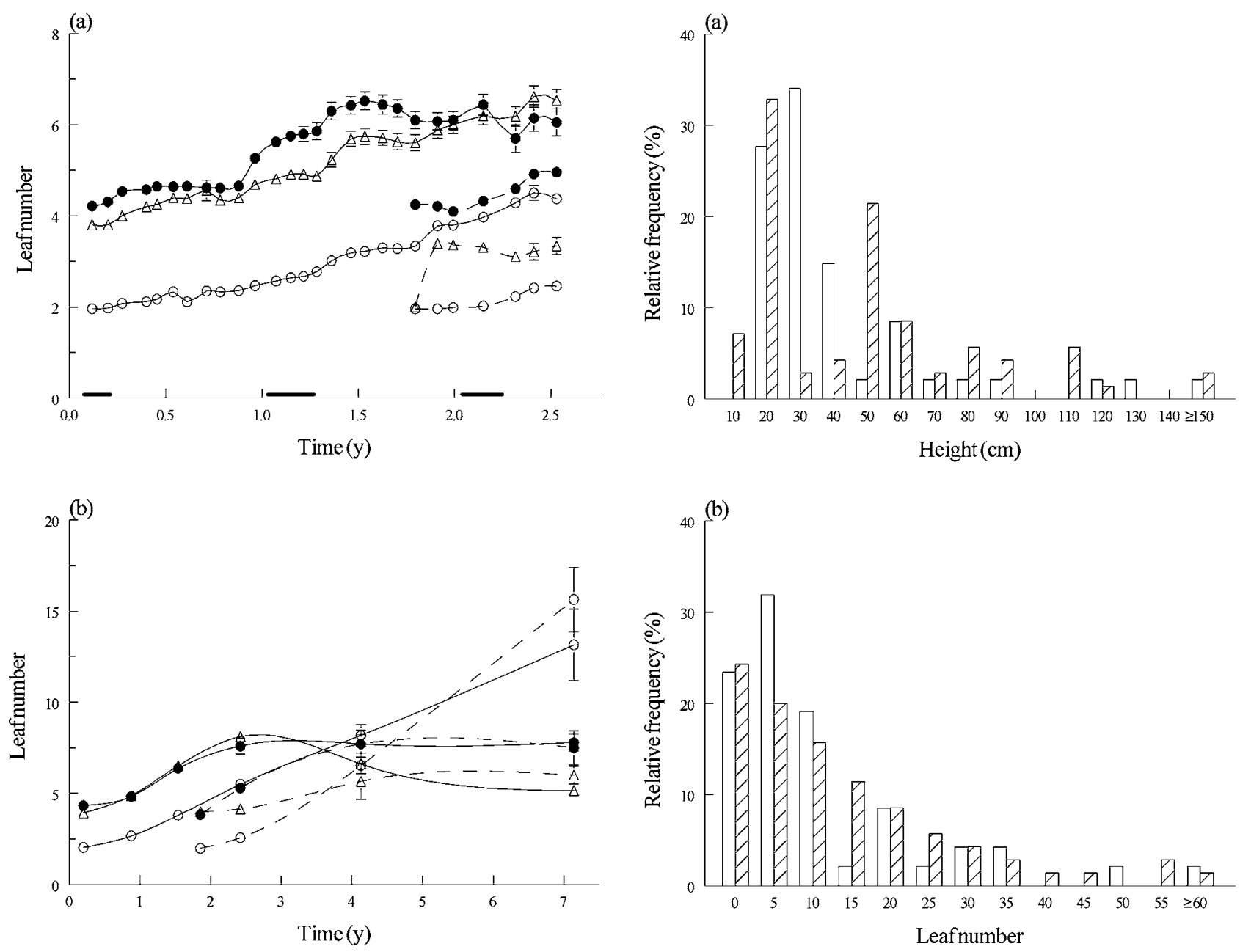

Figure 3. Change in leaf number of seedlings of Microberlinia bisulcata (closed circles), Tetraberlinia korupensis (open circles) and T. bifoliolata (open triangles) in cohort 1 (1995, solid lines) and cohort 2 (1997, dashed lines) from recording times (a) $t_{0}$ to $t_{27}$ and $t_{21} t_{t} t_{27}$, and (b) $t_{0}$ to $t_{30}$ and $t_{21}$ to $t_{30}$. The starting dates were as in Figure 1 , and comments about points and averaging in Figure 2 also apply here. Bars on points show $\pm 1 \mathrm{SE}$. Horizontal bars along the time axis indicate the dry seasons.

having lower heights and less leaves than the late-dying ones. From $t_{11}$ only the late survivors (time interval 4 , i.e. to $t_{25}-t_{30}$ ) showed marked increases in height and leaf number whilst for time intervals 1 to 3 height and leaf number stagnated (Figure 5a,b,e,f). By contrast seedlings of $T$. korupensis were more widely separated in height at $t_{1}-t_{5}$ but the order of time intervals was $1,2,4$ and then 3 (Figure $5 \mathrm{c}$ ): that is seedlings in interval 3 had the greatest heights, and from $t_{1}-t_{18}$ intervals 3 and 4 (longest survivors) had parallel increases in height. For leaf number (Figure 5d) differences between time intervals were less clear, all following a common rise in increasing leaf number, although again interval 3 had the highest mean number of leaves at least until $t_{12}$. The data show that relationships between starting height and

Figure 4. The frequency distribution of (a) heights, and (b) leaf numbers, of Tetraberlinia korupensis seedlings at recording time $t_{30}$ in cohorts 1 (open bars) and 2 (hatched bars). Maximum heights and leaf numbers were $150 \mathrm{~cm}$ and 60 for cohort 1 , and $240 \mathrm{~cm}$ and 74 for cohort 2 , respectively.

leaf number and growth rates were not linearly related to survivorship in a simple way.

The positive dependence of length of survival time between $t_{13}$ and $t_{27}$ on the size and growth of seedlings in the starting period $t_{1}-t_{12}$, was strongly significant for leaf number and rates of height and leaf number growth for M. bisulcata and T. bifoliolata (Table 2) on applying the Cox proportional-hazards model. As the size or rate variable increased the risk of dying decreased: the hazard rate became $<1.0$. Except for height growth rate, the relationships for T. korupensis were not significant. In none of the tree species was survival dependent on height per se. Regressions using initial intervals of $t_{1}$ to either $t_{3}, t_{6}, t_{9}$ or $t_{15}$, and survival in the periods thereafter to $t_{27}$, gave similar but mostly less pronounced results. The lack of dependence in $T$. korupensis corresponds to the lack of order in the growth curves in Figures $5 \mathrm{c}$,d. The 
(a) $\mathrm{Mb}$

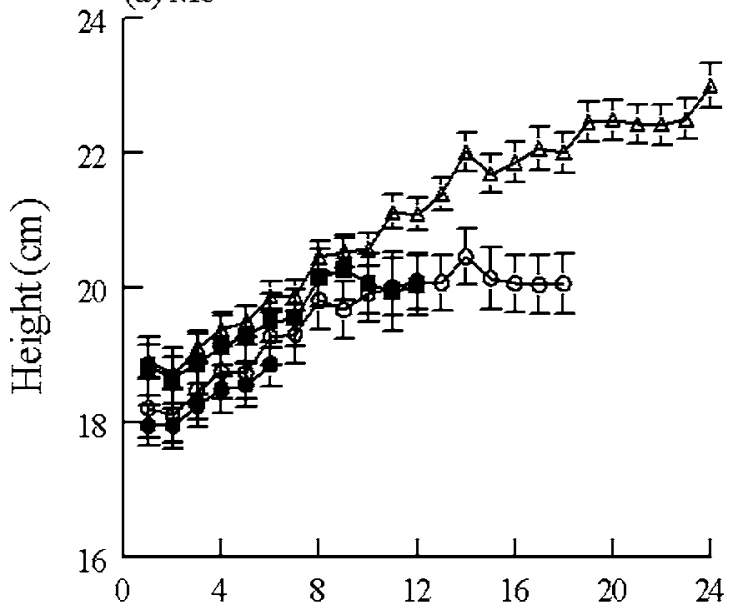

(c) $\mathrm{Tk}$

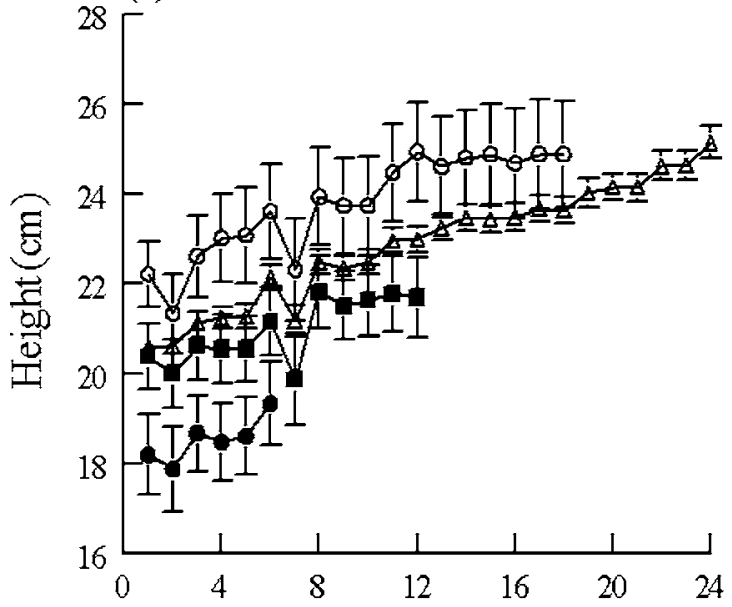

(e) $\mathrm{Tb}$

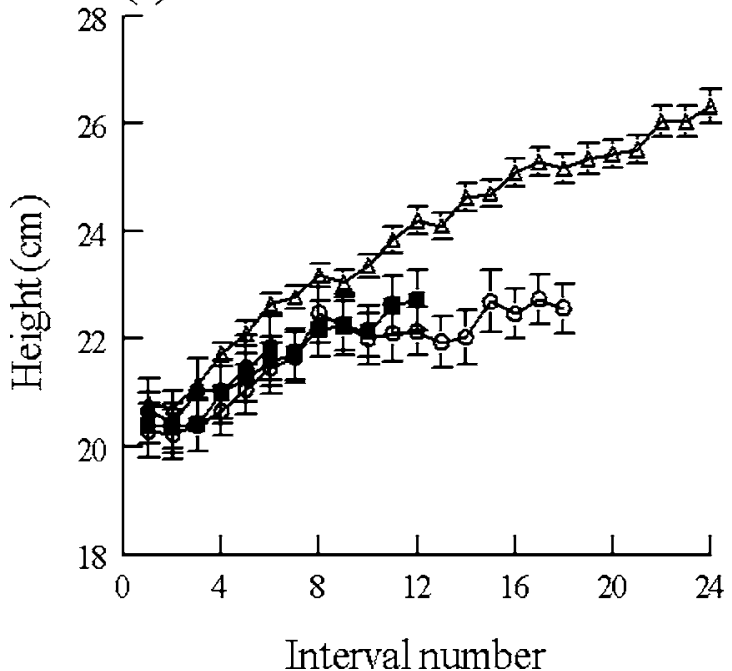

(b)

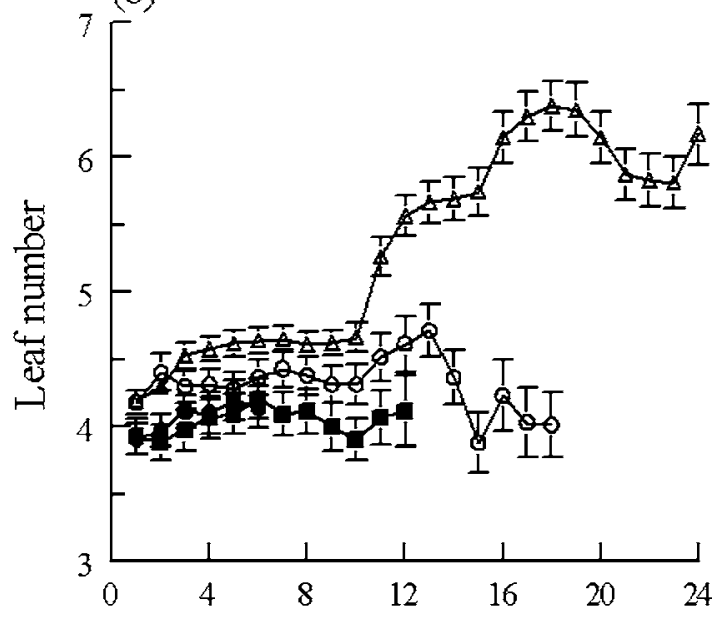

(d)

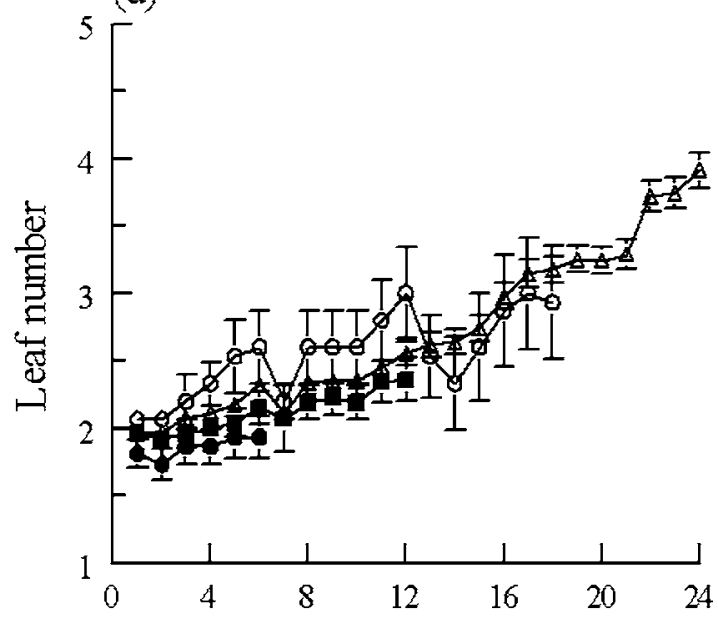

(f)

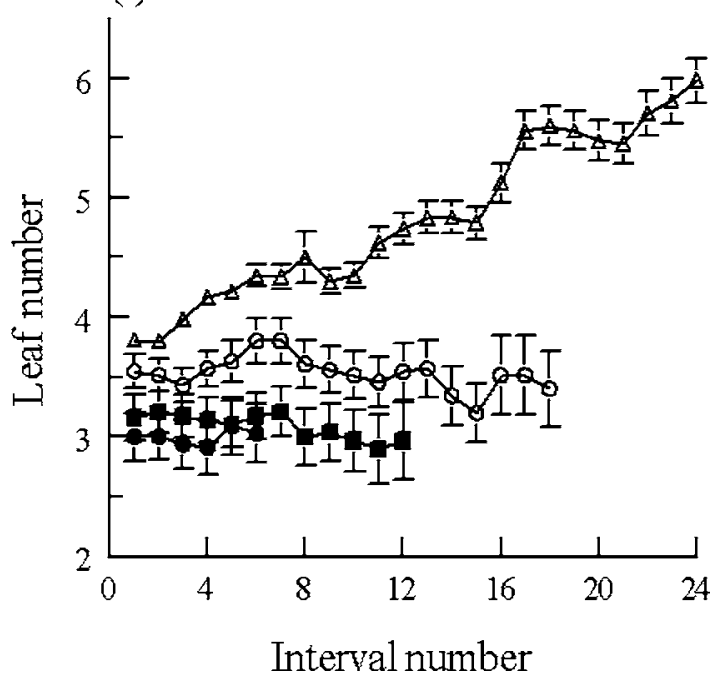

Figure 5. Changes in mean height and leaf number with time (interval number) of survivors of (a,b) Microberlinia bisulcata (Mb), (c,d) Tetraberlinia korupensis (Tk), and (e,f) T. bifoliolata (Tb), to four time intervals: recording times $\mathrm{t}_{7-12}$ (closed circles), $\mathrm{t}_{13-18}$ (closed squares), $\mathrm{t}_{19-24}$ (open circles) and $t_{25-30}$ (open triangles). Bars on points show \pm 1 SE. 
Table 2. Dependence of survival time between $t_{13}$ and $t_{27}$ of cohort 1 (1995) seedlings of Microberlinia bisulcata, Tetraberlinia korupensis and T. bifoliolata on their mean heights and leaf numbers (and absolute growth rates of these) between $t_{1}$ and $t_{12}$, using the Cox proportional hazards model. The exponent of the regression coefficient $(b)$ is the hazard rate (HR). Significance was tested by Wald's statistic $(z)$.

\begin{tabular}{|c|c|c|c|c|c|}
\hline Species & $\mathrm{n}$ & Height & $\begin{array}{l}\text { Height } \\
\text { growth } \\
\text { rate }\end{array}$ & $\begin{array}{c}\text { Leaf } \\
\text { number }\end{array}$ & $\begin{array}{c}\text { Leaf } \\
\text { number } \\
\text { rate }\end{array}$ \\
\hline M. bisulcata & 237 & & & & \\
\hline$b$ & & -0.502 & -0.172 & -0.459 & -0.465 \\
\hline$H R$ & & 0.951 & 0.842 & 0.632 & 0.628 \\
\hline$z$ & & -1.54 & -3.73 & -4.58 & -6.71 \\
\hline$P$ & & 0.124 & $<0.001$ & $<0.001$ & $<0.001$ \\
\hline T. korupensis & 175 & & & & \\
\hline$b$ & & -0.034 & -0.188 & -0.135 & -0.252 \\
\hline$H R$ & & 0.967 & 0.828 & 0.874 & 0.777 \\
\hline$z$ & & -0.68 & -2.39 & -0.45 & -1.45 \\
\hline$P$ & & 0.499 & 0.017 & 0.650 & 0.146 \\
\hline T. bifoliolata & 242 & & & & \\
\hline$b$ & & -0.114 & -0.210 & -0.704 & -0.569 \\
\hline$H R$ & & 0.892 & 0.810 & 0.495 & 0.566 \\
\hline$z$ & & -2.69 & -3.54 & -6.24 & -5.20 \\
\hline$P$ & & 0.007 & $<0.001$ & $<0.001$ & $<0.001$ \\
\hline
\end{tabular}

patterns in survivorship with height were confirmed by making separate Kaplan-Meier survival plots for each of six height classes (mean heights $\mathrm{t}_{1-12}$ ) and finding the survival closest to $t_{24}$. For $T$. korupensis survival was optimal at height classes 3-4 $(20-24 \mathrm{~cm})$.

\section{DISCUSSION}

\section{Differential species' responses}

Microberlinia bisulcata survived the least well of the three species, with approximately half of the numbers of seedlings of the Tetraberlinia spp. alive at $2.5 \mathrm{y}$ and only a quarter of them at $7.1 \mathrm{y}$. Although early establishment losses were significant, so also was the survival over the longer period in distinguishing the species. Seedling cohorts were not obviously influenced by the dry season although a consistent pattern might be difficult to find when each of the first three seasons likely had a different effect on the seedlings as their ontogeny advanced. In the second year, the strongest and fastest growing individuals might have been able to benefit from the temporarily elevated PAR levels and achieve new flushes of leaves. Coincidentally, the first dry season of this study was shorter and less extreme than the two that followed. There was no evidence of density-dependent survivorship for $M$. bisulcata, this confirming the result of Green \& Newbery (2002).

In the first $2.5 \mathrm{y}$, T. bifoliolata was nearly always taller than M. bisulcata and T. korupensis. Relative leaf number was more difficult to compare across species, especially when considered in terms of represented leaf areas. The remarkable trend after $4.1 \mathrm{y}$ was the much better growth of survivors of T. korupensis, compared with the other two species in terms of height and leaf number (Figures $2 \mathrm{~b}$ and $3 \mathrm{~b}$ ), although decline in survivorship was almost the same for all three species in this interval (Figure 1b). Variance of survivors to $7.1 \mathrm{y}$ was considerable for T. korupensis, some seedlings becoming very tall. What was more surprising was that seedlings of T. korupensis in cohort 2 reached larger sizes than those in cohort 1 although they began growing $2 \mathrm{y}$ later, suggesting that they both experienced a common 'release' between 4.1 and $7.1 \mathrm{y}$.

\section{Start of recording}

The recording of the $M$. bisulcata cohort 1 seedlings in 1995 started on 14 December $\left(t_{0}\right)$, which was 3$5 \mathrm{wk}$ after most of the seeds had germinated and the cotyledons had expanded. Already most of them had their first two leaves. Recording of the second cohort in 1997 was earlier in the life-history on 30 September $\left(t_{21}\right)$. This second cohort showed a much steeper early decline in seedling numbers than the first cohort (Figure 1 ), doubtless because losses were fastest earlier on. The nearest calendar date of recording in 1997 to that first one in 1995 was 11 December $\left(t_{24}\right)$, the fourth point on the curve for cohort 2 in Figure 1a. Phenological recordings on parent trees (Newbery et al. 2006) showed that in 1995 the period of seed fall was short and intense in September, whilst in 1997 seed fall was spread less intensely over the months of July and August, i.e. it occurred c. 1 mo earlier in 1997 than in 1995. Thus, if germination and early seedling growth rates can be taken as having the same modus in both years, the equivalent start date (to $t_{0}$ of cohort 1 ) for cohort 2 would be $t_{25}$. By this date 59 , 72 and $50 \%$ of M. bisulcata, T. korupensis and T. bifoliolata respectively had survived (Figure 1a). If cohort 2 were to be set at $100 \%$ at $t_{25}$, the decline in numbers to $t_{27}$ would closely mimic that of cohort 1 between $t_{1}$ and $t_{3}$. Alternatively, the numbers at the second data point (date) for cohort 2 in Figure $1 b$ (average of $t_{25}-t_{27}$ ) could be reset to $100 \%$ and the result would again confirm that $M$. bisulcata declined faster over the longer time period than T. korupensis and T. bifoliolata.

\section{Seedling survival and forest structure}

The similarly better survival of T. korupensis and T. bifoliolata than $M$. bisulcata in cohort 1 was in the inverse of the basal area abundances of the species as adult trees in the plot (stem basal areas of trees $\geq 30 \mathrm{gbh}$ : M. bisulcata 10.55, T. korupensis 2.21, and T. bifoliolata $2.61 \mathrm{~m}^{2} \mathrm{ha}^{-1}$, Newbery et al. 1997; corresponding numbers of trees $\geq 100 \mathrm{~cm}$ stem diameter: 2.06, 0.52 and $0.45 \mathrm{ha}^{-1}$, Newbery et al. 1998). This same result was found with the transplant trials of Green \& Newbery (2001b) after just 
$1 \mathrm{y}$. This suggests a density-dependent process: the greater the adult tree biomass, the lower the species' seedling survival and recruitment.

In a 1989-91 transplant experiment, seedling survival for M. bisulcata, T. korupensis and T. bifoliolata was 33, 76 and 65\% respectively (Newbery et al. 2000), which closely matches values in the present study of 47,70 and $68 \%$ (at 1.66 y, Figure 1). Green \& Newbery (2002) found $67 \%$ survivorship of M. bisulcata, corresponding (at $1.01 \mathrm{y}$ ) to $63 \%$ in the present study. In the transplant study, $T$. korupensis achieved much larger shoot mass than either M. bisulcata or T. bifoliolata ( 1.05 vs 0.34 and $0.61 \mathrm{~g}$ ), and it was the only species to achieve positive growth.

In a survey of 880 quadrats (each $2-\mathrm{m} \times 2-\mathrm{m}$ ) in November 1995 (i.e. sooner after the masting of 1995 than the 14 December start date in this study) the densities of seedlings in the new cohort were 6593, 927 and 3729 ha $^{1}$ for M. bisulcata, T. korupensis and T. bifoliolata, respectively (Newbery et al. 1998). There was a strong dominance by $M$. bisulcata seedlings with the three species in the relative proportions 59: 8: 33\%. However, seedlings $\leq 30 \mathrm{~cm}$ in height in the bank of March 1995 (i.e. before the masting) had densities of 844, 960 and $977 \mathrm{ha}^{-1}$ (30: 35: 35), and those $\geq 30$ in height but $<1 \mathrm{~cm}$ stem diameter occurred at 608, 1116 and $1722 \mathrm{ha}^{-1}$ (18: 32: 50). Finally, small trees in the stem diameter class $1-<10 \mathrm{~cm}$ dbh occurred at 5, 92 and $177 \mathrm{ha}^{-1}$ (2: 34: 64).

The past dynamics may be inferred as follows: $M$. bisulcata started out being relatively very abundant but declined considerably to having very few small trees; $T$. korupensis rose rapidly from being relatively uncommon as small seedlings but being more common as larger ones, and then stabilized its contribution; and finally $T$. bifoliolata started at an intermediate position but increased only much later. Whilst it would be too inaccurate (and too convenient) to match the 2.5- and 7.1-y data in the present study with the $\leq 30-\mathrm{cm}$ height class and $\geq 30-\mathrm{cm}$ height to 1-cm diameter class (and assume stability in population dynamics with time over several mastings), the degree of correspondence is nevertheless very good. In the course of the present $c$. 7-y study M. bisulcata did decline, T. korupensis did increase at this stage around $4-7 \mathrm{y}$, and T. bifoliolata had not by then shown any marked differential growth or survival. If demography were followed for $20 \mathrm{y}$, T. bifoliolata would probably be shown to be released some years after T. korupensis.

Due to the way that their seeds are dispersed, seedlings of the three species were rarely found in balanced mixtures: they tended to occur in patches dominated by one species (Appendix, Table 1). This is an integral aspect of the spatial dynamics in the field and it means that intraspecific interactions are likely to be more important than interspecific ones at the local-quadrat scale in the first years of growth. The demography studied was therefore largely concerned with near single-species populations.

\section{Possible differential mechanism}

Part of the explanation for the better survival of $T$. korupensis and T. bifoliolata compared with M. bisulcata may lie with their seed sizes. Seeds of the former were found to be 2.1- to 2.5-fold greater in mass than the latter ( 1.36 and 1.57 g vs. $0.64 \mathrm{~g}$; Green \& Newbery $2001 \mathrm{a}$ ), and nursery experiments, especially the treatments with low irradiance comparable to those over the quadrats in this study, showed that the heavier-seeded species had better survival and growth in the first year (Green \& Newbery 2001a,b). Small seed size at the start of establishment, combined with subsequently slow growth (and possible susceptibility to pathogens) under low light conditions remains the best explanation for the currently very low recruitment of M. bisulcata in Korup (Augspurger 1983, 1984; Green \& Newbery 2001b, Newbery et al. 1998, 2004). However, seed size does not explain the much better growth of T. korupensis than T. bifoliolata seedlings between 4.1 and $7.1 \mathrm{y}$ found in this study.

In contrast to $M$. bisulcata and T. bifoliolata, the largest seedlings (judged by height above ground and number of leaves) of T. korupensis in the first year were not the ones that survived the longest (Figure 5). To speculate, T. korupensis was probably investing relatively more resources below-ground, to enlarging its root system, than the other species. This strategy may have led to the later growth success of its survivors. Newbery et al. (2000) found root-shoot ratios of M. bisulcata, T. korupensis and T. bifoliolata to be $0.44,0.50$ and 0.37 respectively, suggesting relatively most investment in roots by T. korupensis. Further, T. korupensis, became more heavily colonized by ectomycorrhizas than $M$. bisulcata and T. bifoliolata (Newbery et al. 2000).

In the current study quadrats with T. korupensis seedlings did not have higher mean PAR than those of M. bisulcata and T. bifoliolata, whilst their mean R:FR ratio lay between the other two species' values. This suggests that light was not the primary cause of the differences in growth. These light measurements, furthermore, were made close to $t_{26}$, the time when $T$. korupensis continued its rise in height whilst $M$. bisulcata and T. bifoliolata started to level off (Figure $2 b$ ).

Drawing on results from other field and experimental studies of these three tree species at Korup, the following hypothesis for T. korupensis is offered. This species grew better than the other two later on because it had better P-nutrition, either through a slightly larger and/or better colonized root system (which may have led to more effective mycorrhizal network connections) or a more efficacious mechanism of P-uptake (Smith \& Read 1997). This would have enabled it to respond faster 
than the other species to local increases in PAR, and hence achieve stronger onward growth and recruitment. The exact nature of interactions between these three species' seedlings and their adult trees, via perhaps the putative ectomycorrhizal hyphal network (Alexander 1989b, Simard et al. 1997, 2002), remains unknown, however.

\section{Conclusion}

The central question posed was to what degree the demography of a seedling cohort over $c .7 \mathrm{y}$ could explain the current structure and dynamics of the caesalpiniaceous groves in Korup. Results over the first $3 \mathrm{y}$ indicated the future replacement of M. bisulcata by Tetraberlinia spp. as far as survivorship was concerned, but further recording at 4-7y highlighted how the Tetraberlinia spp. differed from one another in their subsequent growth rates. The present results make an important contribution towards modelling the Aubréville phenomenon in Central African rain forests.

\section{ACKNOWLEDGEMENTS}

We thank the Institute of Agronomic Research (IRAD), Ekona Centre, Buea as host to our project (Head, S. Zok); the Ministries of Forests and Environment (MINEF) and Education, Scientific and Technical Research (MINREST) for permission to research in Cameroon; N. C. Songwe formerly of the Forest Research Station, Kumba, and Korup Project, Mundemba; A. Kembou, Conservator of Korup National Park for support and access to the site; the European Commission (DG XII-contract TS3CT93-0233, 1994-98) and the Swiss National Science Foundation (Grant 3100-066655, 2002-05) for financial support; andE. Abeto and X. M. van der Burgt for technical assistance in the field.

\section{LITERATURE CITED}

ALEXANDER, I. J. 1989a. Systematics and ecology of ectomycorrhizal legumes. Monographs in Systematic Botany of the Missouri Botanical Garden 29:607-624.

ALEXANDER, I. 1989b. Mycorrhizas in tropical forests. Pp. 169-188 in Proctor J. (ed.). Mineral nutrients in tropical forest and savanna ecosystems. Blackwell Scientific Publications, Oxford.

ALEXANDER, I. J. \& HÖGBERG, P. 1986. Ectomycorrhizas of tropical angiospermous trees. New Phytologist 102:541-549.

AUBRÉVILLE, A. 1938. La forêt coloniale: les forêts de l'Afrique occidentale française Société d'Editions Géographiques, Maritimes et Coloniales, Paris. 508 pp.

AUBRÉVILLE, A. 1970. Légumineuses (Césalpinioidées). Tome 9. Flore du Cameroun. Muséum National d'Histoire Naturelle, Paris.
AUGSPURGER, C. K. 1983. Seed dispersal of the tropical tree, Platypodium elegans, and the escape of its seedlings from fungal pathogens. Journal of Ecology 71:759-771.

AUGSPURGER, C. K. 1984. Seedling survival of tropical tree species: interactions of dispersal distance, light-gaps, and pathogens. Ecology 65:1705-1712.

BOTKIN, D. B. 1993. Forest dynamics: an ecological model. Oxford University Press, Oxford. 309 pp.

CLARK, D. B. \& CLARK, D. A. 1987. Population ecology and microhabitat distribution of Dipteryx panamensis, a neotropical rain forest emergent tree. Biotropica 19:236-244.

CONDIT, R., SUKUMAR, R., HUBBELL, S. P. \& FOSTER, R. B. 1998. Predicting population trends from size distributions: a direct test in a tropical tree community. American Naturalist 152:495509.

CONNELL, J. H. 1971. The role of natural enemies in preventing competitive exclusion in some marine animals and rain forest trees. Pp. 298-312 in den Boer, P. J. \& Gradwell, G. R. (eds). Dynamics of numbers in populations. Centre for Agricultural Publication and Documentation, Wageningen.

CONNELL, J. H. \& GREEN, P. T. 2000. Seedling dynamics over thirty-two years in a tropical rain forest tree. Ecology 81:568-584.

CONNELL, J. H. \& LOWMAN, M. D. 1989. Low-diversity tropical rain forests: some possible mechanisms for their existence. American Naturalist 134:88-119.

CONNELL, J. H. \& SLATYER, R. O. 1977. Mechanisms of succession in natural communities and their role in community stability and organization. American Naturalist 111:1119-1144.

CONNELL, J. H., TRACEY, J. G. \& WEBB, L. J. 1984. Compensatory recruitment, growth, and mortality as factors maintaining rain-forest tree diversity. Ecological Monographs 54:141-164.

DEANGELIS, D. L. \& GROSS, L. J. (eds). 1992. Individual-based models and approaches in ecology. Chapman \& Hall, London. 525 pp.

DELISSIO, L. J., PRIMACK, R. B., HALL, P. \& LEE, H. S. 2002. A decade of canopy-tree seedling survival and growth in two Bornean rain forests: persistence and recovery from suppression. Journal of Tropical Ecology 18:645-658.

FORGET, P.-M. 1997. Ten-year seedling dynamics in Vouacapoua americana in French Guiana: a hypothesis. Biotropica 29:124126.

GARTLAN, J. S., NEWBERY, D. M., THOMAS, D. W. \& WATERMAN, P. G. 1986. The influence of topography and soil phosphorus on the vegetation of Korup Forest Reserve, Cameroun. Vegetatio 65:131148.

GREEN, J. J. \& NEWBERY, D. M. 2001a. Light and seed size affect establishment of grove-forming ectomycorrhizal rain forest tree species. New Phytologist 151:271-289.

GREEN, J. J. \& NEWBERY, D. M. 2001b. Shade and leaf loss affect establishment of grove-forming rain forest tree species. New Phytologist 151:291-309.

GREEN, J. J. \& NEWBERY, D. M. 2002. Reproductive investment and seedling survival of the mast-fruiting rain forest tree, Microberlinia bisulcata A. Chév. Plant Ecology 162:169-183.

HARPER, J. L. 1977. The population biology of plants. Academic Press, London. $892 \mathrm{pp}$. 
HART, T. B. 1995. Seed, seedling and sub-canopy survival in monodominant and mixed forests of the Ituri Forest, Africa. Journal of Tropical Ecology 11:443-459.

HORN, H. S. 1974. The ecology of secondary succession. Annual Review of Ecology and Systematics 5:25-37.

HUBBELL, S. P. \& FOSTER, R. B. 1990. Structure, dynamics, and equilibrium status of old growth forest on Barro Colorado Island. Pp. 522-541 in Gentry, A. H. (ed.). Four neotropical rainforests. Yale University Press, New Haven.

HUSTON, M. \& SMITH, T. 1987. Plant succession: life history and competition. American Naturalist 130:168-198.

JANZEN, D. H. 1970. Herbivores and the number of tree species in tropical forests. American Naturalist 104:501-528.

JONES, E. W. 1950. Some aspects of natural regeneration in the Benin rain forest. Empire Forestry Review 29:108-124.

JONES, E. W. 1956. Ecological studies on the rain forest of southern Nigeria IV (continued). The plateau forest of the Okomu Forest Reserve. Journal of Ecology 44:83-117.

KLEINBAUM, D. G. 1996. Survival analysis. Springer-Verlag, New York. $324 \mathrm{pp}$.

LEE, E. T. 1992. Statistical methods for survival data analysis. Wiley and Sons, New York. 482 pp.

LETOUZEY, R. 1968. Étude phytogéographique du Cameroun. P. LeChevalier, Paris. 508 pp.

LETOUZEY, R. 1985. Notice de la carte phytogéographique du Cameroun $\mathrm{Au}$ 1:500 000. Institut de la Carte Internationale de la Végétation, Toulouse, France. 240 pp. (plus maps).

LONGMAN, K. A. \& JENIK, J. 1987. Tropical forest and its environment. (Second edition). Longman Scientific and Technical, Harlow. 347 pp.

NEWBERY, D. M. \& GARTLAN, J. S. 1996. A structural analysis of rain forest at Korup and Douala-Edea, Cameroon. Proceedings of the Royal Society of Edinburgh 104B:177-224.

NEWBERY, D. M., ALEXANDER, I. J., THOMAS, D. W. \& GARTLAN, J. S. 1988. Ectomycorrhizal rain-forest legumes and soil phosphorus in Korup National Park, Cameroon. New Phytologist 109:433-450.

NEWBERY, D. M., ALEXANDER, I. J. \& ROTHER, J. A. 1997. Phosphorus dynamics in a lowland African rain forest: the influence of ectomycorrhizal trees. Ecological Monographs 67:367-409.

NEWBERY, D. M., SONGWE, N. S. \& CHUYONG, G. B. 1998. Phenology and dynamics of an African rainforest at Korup, Cameroon. Pp. 267308 in Newbery, D. M., Prins, H. H. T. \& Brown, N. D. (eds). Dynamics of tropical communities. Blackwell Science, Oxford.

NEWBERY, D. M., ALEXANDER, I. J. \& ROTHER, J. A. 2000. Does proximity to conspecific adults influence the establishment of ectomycorrhizal trees in rain forest? New Phytologist 147:401-409.
NEWBERY, D. M., VAN DER BURGT, X. M. \& MORAVIE, M. A. 2004. Structure and inferred dynamics of a large grove of Microberlinia bisulcata trees in central African rain forest: the possible role of periods of multiple disturbance events. Journal of Tropical Ecology 20:131143.

NEWBERY, D. M., CHUYONG, G. B. \& ZIMMERMANN, L. 2006. Mast fruiting of large ectomycorrhizal African rain forest trees: importance of dry season intensity, and the resource-limitation hypothesis. New Phytologist 170:561-579.

NEWMAN, E. I. 1982. (ed.) The plant community as a working mechanism. Blackwell Scientific Publications, Oxford.

POORTER, L., BONGERS, F., VAN ROMPAEY, R. S. A. R. \& DE KLERK, M. 1996. Regeneration of canopy tree species at five sites in West African moist forest. Forest Ecology and Management 84:61-69.

RICHARDS, P. W. 1996. The tropical rain forest: an ecological study. (Second edition). Cambridge University Press, Cambridge. $575 \mathrm{pp}$.

SCHNELL, R. 1976-77. Introduction à la phytogéographie des pays tropicaux. Vol. 3. La flore et la végétation de l'Afrique tropicale. 1re E 2e partie. Gauthier-Villars, Paris. 470 and 265 pp.

SHUGART, H. H. 1998. Terrestrial ecosystems in changing environments. Cambridge University Press, Cambridge. 537 pp.

SIMARD, S. W., PERRY, D. A., JONES, M. D., MYROLD, D. D., DURALL, D. M. \& MOLINA, R. 1997. Net transfer of carbon between ectomycorrhizal tree species in the field. Nature 388:579582.

SIMARD, S. W., JONES, M. D. \& DURALL, D. M. 2002. Carbon and nutrient fluxes within and between mycorrhizal plants. Pp. 33-74 in van der Heijden, M. G. A. \& Sanders, I. (eds). Mycorrhizal ecology. Springer-Verlag, Berlin.

SMITH, S. E. \& READ, D. J. 1997. Mycorrhizal symbiosis. (Second edition). Academic Press, London. 605 pp.

SWAINE, M. D. 1996. The ecology of tropical forest tree seedlings. UNESCO, Paris; and Parthenon Publishing Group, Carnforth. 340 pp.

SWAINE, M. D. \& HALL, J. B. 1988. The mosaic theory of forest regeneration and the determination of forest composition in Ghana. Journal of Tropical Ecology 4:253-269.

TURNER, I. M. 2001. The ecology of trees in the tropical rain forest. Cambridge University Press, Cambridge. 298 pp.

VANCLAY, J. K. 1994. Modelling forest growth and yield. CAB International, Wallingford. $312 \mathrm{pp.}$

WATT, A. S. 1947. Pattern and process in the plant community. Journal of Ecology 35:1-22.

WHITE, F. 1983. The vegetation of Africa. UNESCO, Paris. 365 pp.

WHITMORE, T. C. 1984. Tropical rain forests of the Far East. (Second edition). Clarendon Press, Oxford. 236 pp. 
Appendix 1. Numbers of seedlings of three species at the start of recording (14 December 1995) in two cohorts 1 (1995) and 2 (1997) in 26 quadrats in Korup National Park: Mb, Microberlinia bisulcata; Tk, Tetraberlinia korupensis; and Tb, T. bifoliolata.

\begin{tabular}{|c|c|c|c|c|c|c|}
\hline \multirow[b]{2}{*}{ quad } & \multicolumn{3}{|c|}{ cohort 1} & \multicolumn{3}{|c|}{ cohort 2} \\
\hline & $\mathrm{Mb}$ & $\mathrm{Tk}$ & $\mathrm{Tb}$ & $\mathrm{Mb}$ & $\mathrm{Tk}$ & $\mathrm{Tb}$ \\
\hline 1 & 32 & 0 & 0 & 11 & 0 & 0 \\
\hline 2 & 4 & 1 & 0 & 7 & 19 & 1 \\
\hline 3 & 0 & 0 & 30 & 0 & 0 & 11 \\
\hline 4 & 21 & 0 & 0 & 3 & 0 & 0 \\
\hline 5 & 8 & 0 & 0 & 1 & 1 & 1 \\
\hline 6 & 15 & 0 & 54 & 0 & 0 & 3 \\
\hline 7 & 20 & 0 & 0 & 10 & 5 & 0 \\
\hline 8 & 3 & 0 & 24 & 2 & 8 & 22 \\
\hline 9 & 3 & 0 & 32 & 0 & 7 & 22 \\
\hline 10 & 22 & 0 & 0 & 7 & 3 & 0 \\
\hline 11 & 26 & 0 & 4 & 20 & 0 & 0 \\
\hline 12 & 0 & 0 & 45 & 3 & 9 & 25 \\
\hline 13 & 53 & 0 & 4 & 32 & 0 & 2 \\
\hline 14 & 0 & 0 & 30 & 0 & 3 & 4 \\
\hline 15 & 13 & 0 & 0 & 7 & 0 & 0 \\
\hline 16 & 126 & 0 & 0 & 22 & 0 & 0 \\
\hline 17 & 5 & 3 & 0 & 11 & 5 & 3 \\
\hline 18 & 1 & 0 & 31 & 9 & 0 & 4 \\
\hline 19 & 1 & 0 & 18 & 3 & 29 & 1 \\
\hline 20 & 3 & 0 & 16 & 6 & 0 & 0 \\
\hline 21 & 0 & 0 & 69 & 0 & 9 & 21 \\
\hline 22 & 3 & 35 & 3 & 13 & 19 & 1 \\
\hline 23 & 23 & 29 & 0 & 19 & 3 & 3 \\
\hline 24 & 1 & 51 & 0 & 4 & 3 & 0 \\
\hline 25 & 0 & 47 & 0 & 0 & 67 & 0 \\
\hline 26 & 8 & 43 & 0 & 10 & 11 & 0 \\
\hline All & 391 & 209 & 360 & 200 & 201 & 124 \\
\hline
\end{tabular}

